\title{
Economic Freedom Under Fiscal Control
}

\author{
Jolanta Gałuszka \\ University of Economics in Katowice, Katowice, Poland
}

\begin{abstract}
This paper explores the relationship between economic freedom especially in the field of tax policy and the political institutions as well. Therefore, the objective of this paper is to answer the following questions: (1) What are the limits of the power of taxation in the modern world? and (2) Is the nature of tax policy a result of the requirements of the economy or the consequence of the policy that is conducted inefficiently? In an attempt to answer these questions the level of the effectiveness of the tax burden and the level of the economic freedom not only in Poland were assessed. Such an assessment has been based on the research conducted by international organizations and national institutions. Polish solutions in this context seem to be particularly important due to the fact that Poland is regarded as the leading economy in the Central and Eastern Europe. On a global scale, especially among the Organization for Economic Cooperation and Development (OECD) countries, a positive trend towards a gradual reduction of the level of the tax burden can be observed. However it should be noted that the taxation is not only the rate, but also the different solutions including the provisions of taxes and administrative environment, which prove the quality of the tax system. While in the case of Poland, the tax rates are at a very favorable level, the other elements (like bureaucracy, transfer pricing regulations, value added tax (VAT) accounting, and taxpayer duties), are regarded as unfriendly. Unfortunately, such an assessment of the tax system is one of the causes of the escape from the taxation into the shadow economy. The article is divided into several parts including the case studies that show the importance of the economic freedom, especially the taxation, as well as global trends in the taxation and its potential consequences in the field of the economic freedom. The last part focuses on the problem of the economic freedom in Poland and the estimation of the Polish tax system from the point of view of Polish entrepreneurs in the years 2001-2013.
\end{abstract}

Keywords: economic freedom vs. tax policy, fiscal consolidation, Polish tax system

\section{Introduction}

The modern economy is now dominated by numerous contradictions. On the one hand, globalization of the world economy and increasing international interdependence are creating a global integrated financial system with unlimited possibilities of economic freedom. On the other hand, a growing state structures intervention can be observed at both national and international levels (European Union (EU), International Monetary Fund (IMF), World Trade Organization (WTO), World Bank, etc.) having a major impact on the nature of law which as a result gives them greater possibility to intervene in the economic freedom. In addition 2008-2009 global financial crisis provides an important testing ground for the public finance. It has become

Jolanta Gałuszka, Ph.D., Finance Department, University of Economics in Katowice.

Correspondence concerning this article should be addressed to Jolanta Gałuszka, ul.Bogucicka 14, 40-226 Katowice, Poland. E-mail: jolanta.galuszka@ue.katowice.pl. 
obvious and clear that certain elements of the Economic and Monetary Union (EMU) system cannot simply work. Disturbances on financial markets, although provoked outside Europe, have immediately exposed these weaknesses. The EMU fiscal regime was too weak to prevent some countries from generating excessive budget deficits. This is how fiscal consolidation programs, which tools are focused on fiscal policy instruments, have become a key way to stabilize their economies and that simply means further state intervention in the functioning of society and economic freedom in some of them. In such circumstances, the level of economic freedom is very important in terms of tax solutions on global scale. Fundamental question arises whether the primacy of public finance does not dominated the ability of taxpayer to meets its fiscal obligations. Moreover, in the countries where the tax system is unfriendly, the tax can be regarded by the taxpayers as a kind of "penalty" for economic and financial success.

\section{Doctrinal Considerations on Economic Freedom}

The concept of the economic freedom has numerous interpretations which means that we should suggest one of them in order to describe its limits. Top-down imposition of certain rules under the law in every area of social and economic life actually signifies to delimitate the boundaries of freedom for which we got the permission from the state. At the same time, it is difficult to expect that an individual will pay taxes and levies by its own choice and real freedom. In most cases the economic freedom is only a kind of constitutional and/or doctrinal postulate. It is subjectively shaped by the legislature and the courts. There is no fixed definition of the economic freedom, as well as the economic activity. The legislature and the courts often shape these notions quite freely.

In fact, even the most liberal fiscal systems (including tax havens) are not free from the constraints of this area. Generally there is no principle of the economic freedom, there is only a principle to limit the economic freedom and such freedom itself is the exception. The economic freedom is a variable phenomenon, the result of taxpayer relationship with the state, the result of the economic and political situations. But the freedom also has other faces. The economic freedom without "moral signpost" especially for those economies in which citizens do not experience proper allocation of public goods leads to the violations of the rule of law, corruption, taxes avoidance, and in the extreme cases, to the anarchy. That is why the extent to which we can talk about the economic freedom for both business development and individuals is directly determined by the institutional frameworks of its legal field.

Since Smith defines determinants of social welfare, attempts have been made to identify the factors that would ensure this prosperity. Smith (1954) saw as the source of the success: the development of trade, the size of the economy, and the economic policy. The reference to Smith's theory can also be seen in the modern literature which does not underestimate the role of the state policy and institutional or economic background, which is increasingly determining the directions of changes through international organizations like the EU, WTO, and OECD, reducing the potential of given economy. However according to Ricardo it is free trade that promotes economic growth (Ricardo, 1912).

Later these assumptions have been developed and extended so that they suit the changing reality. The Smith's theory was supplemented by Solowa who saw the economic growth and social welfare path in the capital, labor, and technology (Solow, 1956). Lucas (1988) and Romer (1990) have extended the Solow's doctrine by emphasizing the special role of human capital in the economic potential of each economy. A key factor was to invest in human potential, especially in education (Lucas, 1988; Romer, 1990). 
These determinants of the economic growth underwent further modifications. Bauer (1972) and North (1990) created the growth theory that emphasized a special role of economic environment. This economic environment was composed of the factors making the development and effective use of resources possible (Gwartney \& Lawson, 2001).

In many studies the particular importance is given to the country financial policy, price stability, protection of property rights, and openness to international cooperation. These factors have impact on the economic growth that is independent from the economic potential (Barro, 1996a, 1996b; Jong-Wha, 1993). Such an approach should have indicated the role of institutions and the nature of monetary and fiscal policies that constituting absolute systemic-normative basis contributes much more to creating a higher economic growth than the potential of the economy. A similar attitude can be found in Gastila, Scully, Leblanga, and Goldsmith's studies, which emphasize the positive correlation between the economic and political freedom and the economic growth. This positive relationships are however not obvious for all. According to Barro (1996a), the determinants of the economic growth and social development can vary in different countries.

While the doctrine has indicated the factors that decide about the economic and social success many times, actually it is difficult to combine theory with economic. In the 1920s of the last century the assessment of the economy in terms of its performance in various aspects including fiscal aspects seemed to be impossible. In 1986 Walker and Friedman initiated series of conferences, the theme of which was to evaluate the economic freedom. As a result of this, the ranking of the economic freedom has been designed.

\section{The Essence of Economic Freedom}

The components of the economic freedom are: undisturbed personal choice, voluntary exchange, protection of human rights and property (Gwartney \& Lawson, 2001). In the economy in which the above rules are preserved an individual decides what is going to be manufactured or marketed. The individual also selects the appropriate instruments that will eventually outweigh the competitiveness in relation to other market participants. As a result, on the one hand, people are dealing with specialization, on the other hand, people are dealing with co-operation. Personal freedom is the foundation upon which the economic freedom is built, which carries above all the freedom to choose that is protected by the institutional framework of government policy. This government policy will promote the economic freedom only if the legal rules indicating rights and obligations are established and implemented. However one should keep in mind that liberal rules may disrupt the implementation of the economic freedom in each country. Moreover the law which on the one hand should protect the economic freedom, on the other hand can provoke numerous obstacles and difficulties leaving in this way the economic freedom only in doctrinal assumptions.

The economic freedom covers different spheres of social relations including political ones. These are: democratic rights of citizens who in accordance to the principles of liberties will take active part in the economic policy of the country. The political freedoms should however be separated from civil liberties. It is considered as clearly defined procedures of public authorities' selection and decision-making on policy issues with respect for the principles of democracy, justice, fairness, and competition.

So the question is whether economic and political freedom may be based on the same principles giving birth to a single, coherent state policy, or maybe whether economics and politics have different purposes so that politics will attempt to subdue the spheres of economic and social life. Mayer (1982) used to say: "Logical consistency is a feature of a good theory, but not necessarily of good policy". 
In the countries where politics plays a primary role of subordinating the other spheres, the economic freedom collides with the barrier of high costs and fiscal burden that undermine its creation. It is also possible that seriously limited political freedom will not disrupt both the economic growth and the economic freedom. A good example is Hong Kong, which being dependent on the British jurisdiction has created the right conditions to make the development of the economic freedom somehow possible. There are also countries confirming that the economic freedom, political and civil liberties can be compatible.

If an individual is left free to decide about the sources of income and the ways it spent, it is likely that it will be deeply convinced of the proper choice of the political authorities. Gwartney and Lawson (2001) assume that if the economic freedom increases, the political freedom will probably increase too. As a confirmation of this thesis they suggest such countries like: Chile, Taiwan, and South Korea.

There are also some reasons to believe that the political freedom and the civil liberties strengthen the economic freedom. This is particularly reflected in the legal system. A clear, transparent, fair, and relatively stable legal system can be an important base and foundation for the political freedom like it takes place in a case of Switzerland which in skillful manner combined economic and political freedom in one integral whole with a high share of each individual in making of national law.

\section{Determinants of Economic Freedom}

Determining the level of the economic freedom, the following questions arise. Firstly, if it is possible to measure the economic freedom, is it also possible to examine the strength of the direct relationship between the economic freedom and the economic growth? Secondly, can the economic freedom be compared with the other factors that are not included in the index of the economic freedom but affect the economic growth? As a result of these questions Friedman stresses the need to continue the work on a catalog of indicators and on modification of research methodology, which will enable to assess the actual level and the degree of the economic freedom (Gwartney \& Lawson, 2001). The measures of the institutional and policy environment are derived from the economic freedom of the world index produced by Gwartney and Lawson (2001) and the Heritage Foundation, the Index of Economic Freedom (IEF), which are widely used in empirical cross-country studies. With regard to the index published in economic freedom of the world, 42 variables are used to construct a summary index and to measure the degree of economic freedom in five broad areas:

(1) Size of government;

(2) Legal system and property rights;

(3) Sound money;

(4) Freedom to trade internationally;

(5) Regulation.

IEF economic freedom indicator is defined in the range of 0 to 10 (the countries with the highest economic freedom index achieve 10 points, while with the lowest 0). Gwartney and Lawson (2001) (based on three different annual reports: the Global Competitiveness Report, the World Competitiveness Yearbook, and the International Country Risk Guide) decided to build the index which would be the best measure of the extent to which government policy and its institutions support the economic freedom. According to them the foundation on which the economic liberties can be build is freedom to make individual choices, to trade without normative tariff barriers to entry to the market and to compete on it while respecting and protecting private property. 
The index of the economic freedom-The Heritage Foundation: The IEF is based on the analysis of 50 variables describing the socio-economic development grouping them into 10 categories:

(1) Trade policy;

(2) Tax burden;

(3) Government intervention in the economy;

(4) Monetary policy;

(5) Flow of capital and foreign investment;

(6) Banking and finance;

(7) Wages and prices;

(8) Property rights;

(9) Legal solutions;

(10) Activity of shadow economy;

All EFW ratings are based on 0-10 scale. Countries receive higher ratings when government interference in the form of taxes, spending, and regulations are lower, and also when government does a reasonably effective job in enforcing property rights and providing a stable monetary regime. Of particular interest in this study is the component measuring marginal tax rates. This component computes the marginal tax rate applying to the highest income earners, including any applicable state and local income taxes (Clark \& Lawson, 2008, p. 26).

Overall rating is the average of these 10 categories. On the one hand, the rating that is based on specific determinants refers to climate of freedom in the country giving the testimony in its positions, on the other hand it allows to compare different areas, which have a decisive impact on the economy and its development. This last issue is particularly important for those countries that have passed the period of economic downturn or economic changes, deriving the knowledge and experience from these economies that have achieved the economic success using specific instruments. However one should keep in mind one very important fact that the amount of the assessment of individual countries and their economies in these areas are at the same time the assessment of public institutions.

The institutions are usually defined as the rules of the game and they may be informal or formal. Informal institutions may be, for example, customs, norms, and social networks. Among the formal institutions we find political and economic prerequisites such as polity, judiciary, and bureaucracy. Institutions are highly influential for the incentive structure in a society and hence affect economic performance. The literature shows indisputably that the quality of institutions is crucial for creating economic growth in a society. Given the important role institutions play in shaping the incentive structure in a society, institutions can obviously be expected to be influential in a person's decision, for example, to become an entrepreneur (Nyström, 2008, p. 270).

In this case, particular importance is the nature of fiscal policy through which the state with a functioning legal system trespass into the property rights of taxpayer. Recently tax and other fiscal burdens have become particularly important as they became main "actors" of fiscal consolidation programs. It is true that for the most part of changes and reforms taken, the fiscal consolidation was in two thirds based on the activities to limit spending and in one third on the increase of revenues (see Figure 1), but it does not mean that they have social approval. 


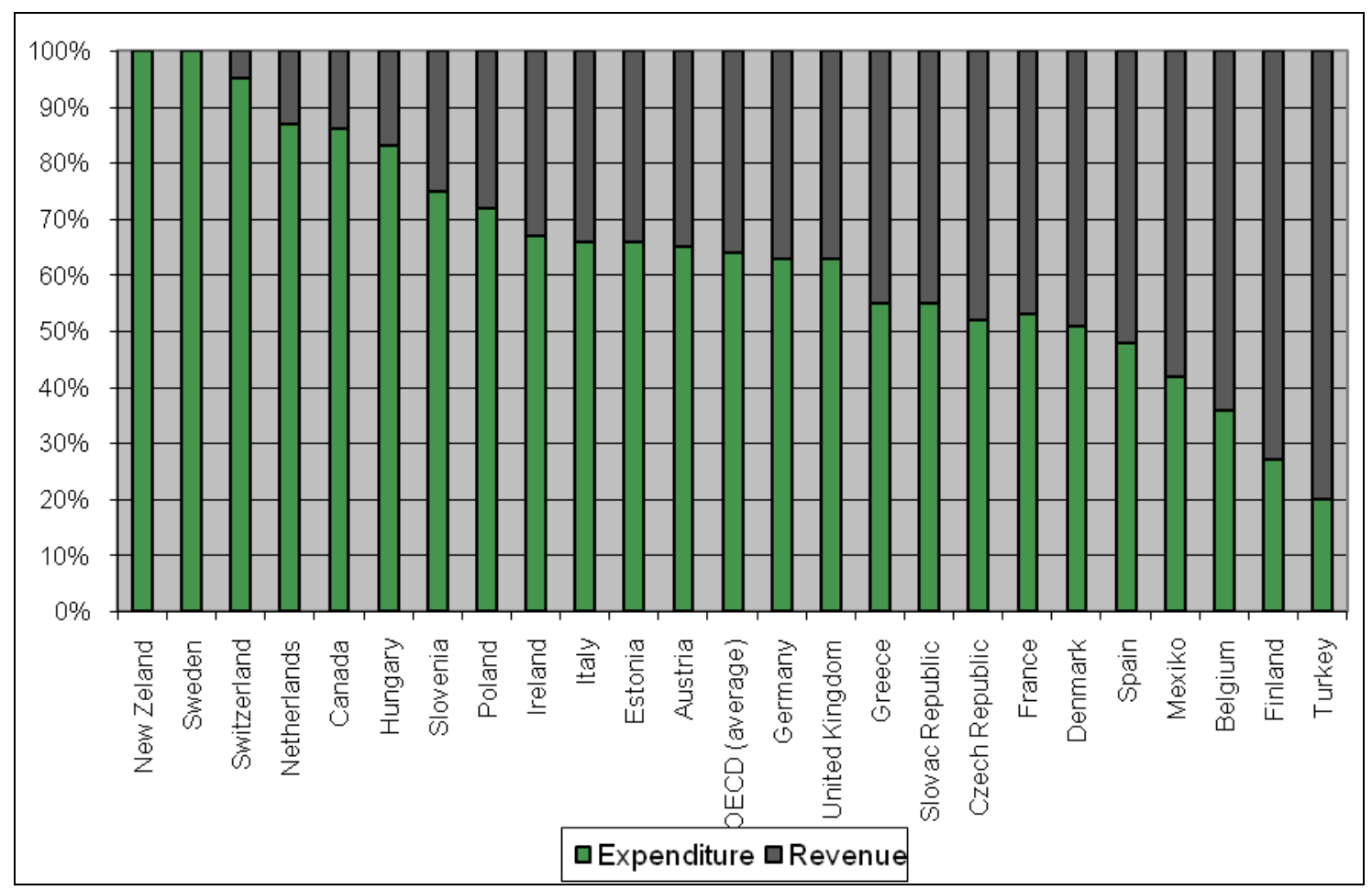

Figure 1. Expenditure versus revenue expenditure of consolidation measures taken (2010). Source: OECD (2011).

Tax is an important instrument of the fiscal consolidation plans, in which ongoing reforms in tax policy will be the consensus of goals and tasks in the long term, and will help to reduce the debt-to-GDP ratio, to increase the savings and investments, to attract investments, to increase labor supply, and thus to stimulate the economic growth (OECD, 2010, p. 112).

The idea of using fiscal policy to boost the economy during a downturn was favoured by Keynes in the 1930s (Brannon \& Edwards, 2009). Tax policy and other government policies are likely to impact both economic growth and income inequality, which in turn may be related to each other. However, economic policy is about more than just tax policy. Property rights, monetary policy, trade policy, and general government spending may also matter (Clark \& Lawson, 2008, pp. 27-28).

The empirical studies focus principally on the relationship between economic growth on the one hand and economic freedom on the other hand. The idea that economic freedom is important for economic growth has been a cornerstone in economic theory for a long time and was emphasized already by Smith (1776), who introduced the role of "the invisible hand" for well-functioning markets, and Ricardo (1812), who endorsed free trade as crucial for economic development. In several empirical studies, the economic freedom index published by the Fraser Institute (Gwartney, Lawson, \& Easterly, 2006) has been used to relate the institutions of economic freedom to variables such as growth and income inequality (Nyström, 2008, p. 270).

The taxes can be used in a way socially and economically desirable, they can also be an ally of the economic growth that will translate positively into reduction of public finance deficit, while at the same time controlling the level of public debt. As a result the tax system is treated and considered as a special element of government regulation of private sector but in some circumstances it can be perceived as an important barrier to increase the economic activity too, leading to deterioration of public finances. According to the OECD analysis, 
it is assumed that the income tax that average share in OECD countries is 35 percent of GDP has negative impact on the private sector acting adversely on production, investment, innovation, and job market.

The justification for the use of these tax programs of consolidation is a result of the fact that not all tax categories will interfere to the same extent the functioning of the private sector and consequently have negative impact on the economic growth of the country. Such a situation is partly dictated by the function of time. Behavioral responses are more likely in the long term than shorter one. Certainly one of the most sensitive taxes is the corporate income tax and capital gains tax, of which technical elements in different countries derive from a high internationalization of capital mobility, the growing importance of cross-border services, and the increased role of multinational corporations.

The taxes that have a neutral impact on the economic growth are the consumption taxes, such as value added tax (VAT), especially when it has a wide range of tax base (Brys, 2011, p. 104). On the other hand, when the VAT rate is too high, it increases the prices of consumer goods reducing the real income of consumers. The rate of the economic growth in such situation may be in fact weakened due to demand that has been significantly reduced.

OECD has been working with its own members as well as with non-member governments and other organizations to restore economic stabilization and expansion, with a central part of this effort including the position that governments must be cautious not to reduce economic freedoms as they seek ways in which to strengthen and revitalize their economies. In other words, nations are strongly encouraged to continue to support and promote economic freedom while implementing domestic economic policies. Clearly, the concern of the OECD (2009a, p. 1; 2009b, p. 1) in this context is that a reduction in economic freedoms will result over time in diminished economic growth (Cebula, 2011, p. 3). Such a position was presented by the OECD in 2009.

In addition, Egger and Winner (2004) have confirmed a strong correlation between economic freedom and business taxes. They argue that an economically free environment improves the attractiveness of a location, which, in turn, enables governments to levy higher business taxes. To test this hypothesis empirically, we estimate the impact of economic freedom on the national tax policy, where the latter is measured by the corporate tax revenue related to gross national product (GNP) (corporate tax ratio). From a firm perspective, a low level of economic freedom, such as private ownership rights, viability of contracts, or rule of law, raises the risk-related costs, and this causes a trade-off between the tax burden and economic freedom in the firms' locational decision. Accordingly, governments may impose a higher tax burden, if they are able to provide a high level of economic freedom without running at risk of firm or plant de-location (Egger \& Winner, 2004, p. 284).

In 2013 in the report addressing Base Erosion and Profit Shifting (BEPS), OECD proposes to expand the international taxing powers of governments (OECD, 2013). In order to address base erosion and profit shifting which is fundamentally due to a large number of interacting factors, a comprehensive action plan should be developed quickly. The main purpose of that plan would be to provide countries with instruments, domestic and international, aiming at better aligning rights to tax with real economic activity (OECD, 2013, p. 51). According to Mitchell (2013), the new OECD report calls for more tax rules on companies but does not acknowledge that governments already have immense powers to restrict corporate tax planning through "transfer pricing" rules and other regulations. However such coordinated action to raise taxes would come at the expense of economic freedom and economic growth (Mitchell, 2013). 


\section{Fiscal Regime and Scope of Economic Freedom-Trends in Tax Systems}

Since 1980, the gradual, but very systematic trend to liberalize governmental economic policies can be observed in more and more countries. Although this liberalization has various degrees, "common denominator" is to achieve such a level of the economic development, which will allow for the implementation of the principles of the economic freedom. As a result, today the actions of governments not only include monetary and trade policy that tries to ease or even eliminate tariff and non-tariff barriers, but also include tax policy.

The average rate of inflation has fallen from 14 percent in 1980 to four percent in 2007. Only 17 of 93 countries examined in 2003-2007 reported a double-digit inflation. The average rate of tariff rate has been reduced from 26.2 percent to 9.0 percent. The number of countries that used to have marginal tariff rate (50\%) has fallen from 62 percent to nine percent. In 1980, 50 countries had non-tariff instruments of control that stimulated the growth of the shadow economy which share was estimated at 10\%. In 2007 there were only three percent. In 2005 income per capita has increased from $\$ 5,400$ in 1980 to $\$ 8,500$ (Shleifer, 2009).

The economic development was impressive so it affected the most important economic indicators improving not only the level of the economic freedom, but also positions of individual countries in different rankings. These trends have also been expressing the flexibility with which the political structures adapt to the economic environment. Moreover the liberalization of these relationships is also a proof of synchronization of the economic freedom and the political freedom, specifying after all the first one that is determined by the number and burdensome of the dos and don'ts which we have to follow.

A special place in the government policy is reserved for fiscal policy, which is the reflection of the state economy and its possibilities. On the one hand the state intervention through taxes can have a stimulating effect on the scope of the implemented economic freedom, on the other hand it can effectively distort the effects achieved by different factors that have helped to improve the levels of the economic freedom. However it should be noted that the tax and more exactly its amount is not a key instrument in global market game, but in the assessment of individual economy that cannot be ignored. The importance of the tax should be assessed in conjunction with other elements of the fiscal policy, which ultimately may affect the rate of growth of GDP.

As previously indicated the degree of the economic freedom is defined by a wide range of instruments of the state intervention and therefore the tax system constitutes an integral component of the economic freedom. The awareness of the duty to pay the taxes does not necessarily provoke resentment. In such countries as Switzerland, Ireland, Singapore, or even Hong Kong, the tax system is the flagship of each of them agreeing the interests of the state and its citizens. But it does not mean that the tax system should be simple. Table 1 presents those tax systems in case of some tax payment is simple and does not cause taxpayer problems. Unfortunately Switzerland has not been indicated despite the fact that its tax system fulfills already mentioned requirements even if it is sometimes complicated. Table 1 also shows the countries with the most complex systems and with the difficulties to meet the tax obligations.

The summary in Table 1 can be compared to the index of economic freedom (EFW), which confirms that the structure of the tax systems, tax laws, and high levels of the economic freedom are correlated. In addition, this proves that the tax can be seen as a special component of the economic freedom. The relationships between the tax system and the level of the economic freedom can also be found in the existing of the shadow economy, which can be strengthened by the excessive fiscal policy combined with a number of other legislative and tariff restrictions. Table 2 shows the relationship between the share of the shadow economy and the amount of the tax burden. This also confirms the connection between both. 
Table 1

Ten Countries With the Simplest and the Most Complex Procedures to Pay Taxes in the World in 2009

\begin{tabular}{|c|c|c|c|c|c|}
\hline \multicolumn{2}{|c|}{ Countries with the most favorable fiscal arrangements: ranking } & \multirow{2}{*}{$\begin{array}{l}\text { Rank } \\
\text { ni }\end{array}$} & \multicolumn{2}{|c|}{ Countries with the worst fiscal solutions: ranking } & \multirow{2}{*}{$\begin{array}{l}\text { Rank } \\
\text { ni }\end{array}$} \\
\hline Maldives & 1 & & Jamaica & 174 & \\
\hline Qatar & 2 & ni & Mauretania & 175 & 109 \\
\hline Hong Kong, China & 3 & 1 & Gambia & 176 & ni \\
\hline United Arab Emirates & 4 & 19 & Bolivia & 177 & 103 \\
\hline Singapore & 5 & 2 & Uzbekistan & 178 & ni \\
\hline Ireland & 6 & 7 & Central African Republic & 179 & 136 \\
\hline South Arabia & 7 & $\mathrm{ni}$ & Congo & 180 & 134 \\
\hline Oman & 8 & 36 & Ukraine & 181 & 128 \\
\hline New Zealand & 9 & 3 & Venezuela & 182 & 138 \\
\hline Kiribati & 10 & ni & Belarus & 183 & ni \\
\hline
\end{tabular}

Note. ni: no information; Source: World Bank, 2010, p. 11.

Table 2

Share of the Shadow Economy in the Countries With the Highest and the Lowest Tax Burden as a Percent of GDP

\begin{tabular}{ll}
\hline Countries with the lowest tax burden & Countries with the highest tax burden \\
\hline Hong Kong (1) $17 \%$ & India (86) $26 \%$ \\
Singapore (2) $14 \%$ & Germany (27) $17 \%$ \\
Switzerland (4) $9 \%$ & Italy (61) $26 \%$ \\
United States (6) $8 \%$ & Sweden (40) $18 \%$ \\
Ireland (7) $15 \%$ & Greece (52) $28 \%$ \\
\hline
\end{tabular}

Note. Source: Schneider, 2006 and Mitchell, 2007.

Surely in the countries with a large fiscalism, it is harder to build a stable and long-lasting foundations for the economic freedom. The tax and quasi-tax have signs of injustice, so if this instrument is abused the natural reaction will be to try to minimize its "burden" or at least to avoid it which means the strengthening of the shadow economy. This thesis finds its confirmation in the literature of the IMF that studied the phenomenon of the shadow economy in terms of micro- and macro-economics. According to Schneider, the increasing taxes and quasi-taxes under the form of social security contributions are the reasons of the shadow economy, its size and strength. Differences between the shadow economy and the formal economy generated by the overall cost of labor and wage rates are attractive and inspiring to certain behaviors for both employee and employer (Schneider \& Enste, 2002). Fiscal source of the shadow economy has been highlighted for many years not only on the national, but also international scene (Braun \& Loayza, 1994; OECD, 1998; Jahnson, 1998).

But still the question is: "What makes a tax system good in the full sense of this term?". According to Paying Taxes 2010 Report the features of good tax system are as follows:

- Clear objectives of the fiscal policy particularly on public spending;

- Strategic nature of the tax system which will correspond to the principles of justice, stability, and consistency that attracts investments stimulating the development of international trade in the long term but also encouraging changes in citizens' mentality and behavior;

- Plausibility, efficiency, and transparency of legislative solutions that will minimize the complexity of 
administrative procedures and, above all, be based on valid sources of law, and not on the interpretation of the provisions made by the structure of the tax administration;

- Respect of ethics and trust between taxpayers and tax authorities.

As particular importance is a positive correlation between the increase in the economic freedom that stimulates and accelerates the economic growth and a higher increase in per capita income. Knowing the source of the economic growth and prosperity is not surprising the positive result in further improvement of social welfare (OECD, 2009). The countries where the tax system is evaluated very positively occupy leading positions in the international rankings (see Table 3).

Table 3

List of 20 Countries With Regard to the Level of Economic Freedom in 2007

\begin{tabular}{|c|c|c|}
\hline Country & Rank & Mark \\
\hline Hong Kong & 1 & 8.97 \\
\hline Singapore & 2 & 8.66 \\
\hline New Zealand & 3 & 8.30 \\
\hline Switzerland & 4 & 8.19 \\
\hline Chile & 5 & 8.14 \\
\hline USA & 6 & 8.06 \\
\hline Ireland & 7 & 7.98 \\
\hline Canada & 8 & 7.91 \\
\hline Australia & 9 & 7.89 \\
\hline Great Britain & 9 & 7.89 \\
\hline Estonia & 11 & 7.81 \\
\hline Denmark & 12 & 7.74 \\
\hline Austria & 13 & 7.67 \\
\hline Luxembourg & 14 & 7.65 \\
\hline Panama & 14 & 7.65 \\
\hline Finland & 16 & 7.62 \\
\hline Mauritius & 16 & 7.62 \\
\hline Taiwan & 16 & 7.62 \\
\hline United Arab Emirates & 19 & 7.58 \\
\hline Bahrain & 20 & 7.56 \\
\hline Costa Rica & 20 & 7.56 \\
\hline The Netherlands & 20 & 7.56 \\
\hline Poland & 74 & 6.78 \\
\hline
\end{tabular}

Note. Source: Fraser Institute and Cato Institute, 2009, p. 10.

In the group of such countries there is also Switzerland (see Table 3) where the tax system primarily due to the federal constitution is not the easiest one, but the low tax rates and competitive legislative solutions significantly affect its competitiveness especially in comparison with other European countries in particular the member states of the EU which after integration have been deprived of freedom to create their own tax law.

As matter of increasing government control over tax policy and tax revenues in recent time there is a discussed problem of disclosure of tax information, especially in the business sector. In 2011, Oxford 
University Centre for Business Studies examined the financial reporting of information country-by-country in its report "Transparency in reporting financial data by multinational corporations" (Devereux, 2011). The essence of the report was to indicate whether greater transparency could assist developing countries by providing the necessary tax information to hold tax revenues and payments in their countries for the activities multinational companies operating in their territory. The report suggests that country-by-country reporting of tax payments on the one hand will not be an effective instrument unless governments include some measure of country-by-country profit (some kind of profitability ratio as an international standard). But on the other hand the ratio will be less effective due to the shifting of profits, and this will reduce both reported earnings and the amount of taxes.

According to the World Bank studies, 78 percent of analysed countries surveyed possessed financial disclosure system, of which 42 percent revealed information to the public opinion. In general, the countries which use disclosure of tax information are very few, they are: Finland, Sweden, Iceland, Norway, and in the past U.S., Japan, and France (OECD, 2010b).

The basic conclusion, what comes to mind is the fact that the tax disclosure system cannot replace the role of government, and thus to be a remedy to improve the tax income of the budget. While legitimate and necessary is that greater openness and transparency in the field of certain tax data is necessary between collaborating agencies of public authorities, while in the studies it is difficult to find sufficiently justified economic and social arguments for full tax information disclosure (Hasegawa, Hoopes, Ishida, \& Slemrod, 2012). What is more, the empirical studies confirm the negative correlation between openness and tax disclosure to improve reliability of income.

The practice of public disclosure of financial information, in particular the tax information is a matter of very controversy regardless of the form in which it would be carried in each country. It seems that disclosing such specific information has the same advantages and disadvantages as well. Moreover, the fundamental question arises whether such a serious interference does not violate the human rights but also economic freedom?

\section{Case of Poland}

The survey carried out by Gallup in March 2001, as well as the data from the Ministry of Economy, clearly shows that the major obstacle that stops the development of entrepreneurship in Poland is the tax system (see Figure 2).

In the opinion of the Polish entrepreneurs, it is the shape of the law, not its function, that is particularly unfriendly to taxpayers. The broad interpretation and analogy in the tax law are more likely than other factors to affect the development of the economic freedom or to distort its overall assessment seriously. Since 2001 the Polish law has undergone numerous changes and modifications which have, without doubt, contributed to a better assessment of the tax rates, including the introduction of proportional taxation in the case of individuals' income leaving the taxpayer conducting non-agricultural business a choice between progressive and proportional scale.

Despite this, many tax areas still remain very negatively evaluated not only by traders but also by the international institutions. A good example is the VAT legislation, more specifically the directive under the law on tax on goods and services which rests ambiguous and because of a wide scope of subjects included lower the assessment of the Polish tax system, and as a result the economic freedom. 


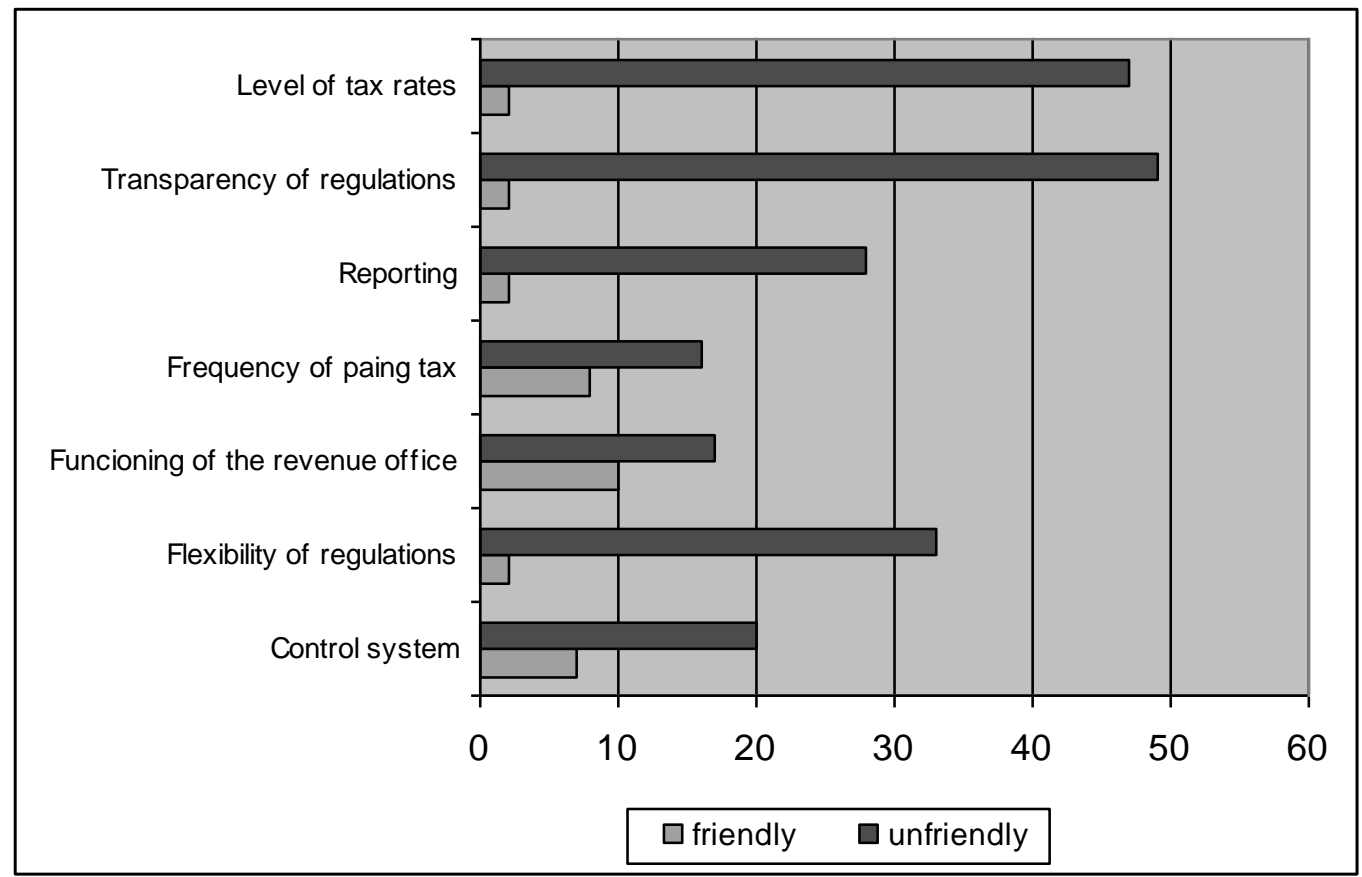

Figure 2. Entrepreneurs' opinions on the polish tax system in 2001. Source: Entrepreneurs' opinions on the tax system, Gallup Institute, ordered by the Polish Agency for Enterprise Development, March 2001.

Number of declaration and information for the preparation

Transfer Pricing

Inconvinient tax dates (too short)

Tax audits

VAT accounting (settlement)

Collection withholding tax from the payment abroad

Preparing annual tax declaration (corporate income tax)

Duties of the payer in the field of personal income tax

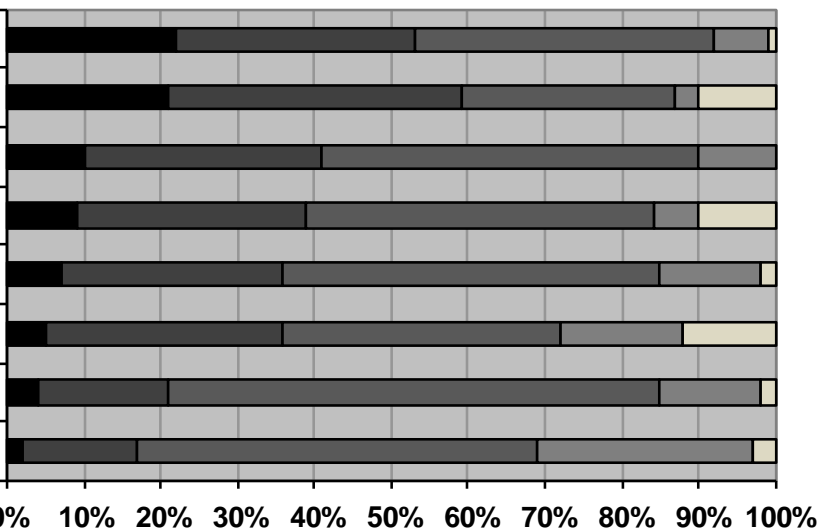

- Very problematic, complicated

- Moderately problematic ,complicated

- Problematic, complicated

$\square$ It doesn't cause problems

$\square$ Not applicable

Figure 3. Entrepreneurs' opinions on the polish tax system in 2013. Source: The Polish tax system in the evaluation of the III Congress of KPMG Tax and Accounting 2013.

A few years later the assessment of the Polish tax system has changed only a little. The Polish entrepreneurs think that the most important barriers in doing a business are a high cost of labor (social security), unstable law, and delays in payment. According to them it is not only the state fault, but also the entrepreneurs 
who exploit loopholes in the law and the failure of the system. In 2013, the situation improved slightly (see Figure 3).

According to the Economic Freedom Ratings for 2010, in 2007 Poland took 74 place 141 economies assessed, in 2010 it was 48, but still it is difficult to talk about success. Without doubt a low assessment was a consequence of the Polish tax system, in which, despite the changes, it is difficult to find values of clarity, fairness, and stability. The report of the World Bank, the International Finance Corporation (IFC), and consulting firm PwC focuses on 185 countries. In the document "Paying Taxes 2013", Poland was ranked on 114 position. This meant that the position of Poland has improved since 2012 (position 127). According to the World Bank experts, the Polish tax system is still too complicated and the tax settlement takes a lot of time-286 hours/year (see Figure 3).

Such a negative assessment of the tax system in Poland means that the entrepreneurs rarely take actions to create the tax strategy in their firms using legal tax tools. The attitude of the entrepreneurs towards such an important element of the financial management of the company as the taxation should be more active and consistent. Undoubtedly, the reason of this is insufficient information on financial aspects of leading company including knowledge about tax regulations. In the field of the taxation the entrepreneurs are primarily focused on the proper fulfilment of the statutory requirements relating to the use of the tax strategy. Taking into account the financial implications of the settlement of a tax, the conservative attitude of the entrepreneurs towards the use of the tax strategy can also be linked to the fears of government's fiscal response to the reduction of tax liabilities.

The active tax strategy requires from entrepreneurs the decisiveness in pursuit of a assumed goal, which should be supported by the relevant knowledge and awareness of the rights under, inter alia, the tax regulations. Such an attitude should also be supported by the state, including fiscal authority.

Unfortunately the fiscal consolidation program realizing in Poland is violating the principle of the economic freedom and the economic activity. Moreover such practices are increasing the propensity of entrepreneurs and workers to escape in the shadow economy. There will always be some part of society that will not be willing to agree with the policy of the state, and hence its financing. As a result the principles of revenue redistribution are putted under the sharp criticism especially when the financial success is transformed into higher and higher tax burden that has been defines as a tax on success. That is why in the Carlsson and Lundström's (2002) opinion: It is not only important to analyze an overall index of economic freedom, but it is also important to "investigate which components of the economic freedom indices that are important for growth and the direction of these effects".

\section{Conclusions}

An integral component of the economic freedom is the tax system, which is a kind of compromise between the need to obtain the tax revenues - the basis of the state functions and its tasks - and the freedom of making activity. However there are some examples of how the tax system came effectively used to achieve the objectives of both economic and social. A factor that will positively affect the liberalization of tax solutions is the internationalization of the economy. Individual countries around the world, regardless of their disapproval, gradually, but steadily began to undergo a process of globalization, which, in turn, has intensified competition, which also embraced the tax systems. The data presented in the article clearly show that the tax system, its structure, tax rates, and the legal basis for the fiscal policy can initiate positive stimuli, which on the one hand 
can contribute to the improvement of economic and social welfare, on the other hand can constitute a formal framework for the economic activity, which in combination with other factors determine the level of the economic freedom. The need to pay taxes is not in doubt. If the legitimacy of the state and other public-sector institutions at the international level is recognized, the need to incur financial sacrifices also has to be recognized by members of the national community. These financial sacrifices as Thomas Aquinas said must be borne bono communi regionis sui (for common good). However, the fundamental question concerns the limits of the tax burden. It should be remembered that the tax is a source of eternal conflicts between public and private interests that are reflected by the supporters of economic liberalism. The idea of the economic freedom has led to the proclamation of such principles of the tax and the tax system, which encourage this freedom rather than restrict it.

\section{References}

Barro, R. J. (1996a). Democracy and growth. Journal of Economic Growth, 1, 1-27.

Barro, R. J. (1996b). Inflation and growth. Federal Reserve Bank of St Louis Review, 78(3), 153-169.

Bauer, P. T. (1972). Dissent on development: Studies and debates in development economics. Cambridge: Harvard University Press.

Brannon, I., \& Edwards, C. (2009). The troubling return of Keynesianism. Retrieved from http://www.cato.org/sites/cato.org/files/pubs/pdf/tbb_0109-52.pdf

Braun, J., \& Loayza, N. V. (1994). Taxation, public services and the informal sector in a model of endogenous growth. World Bank Policy Research Working Paper, No. 1334.

Brys, B. (2011). Making fundamental tax reform happen. OECD Taxation Working Papers No. 3, Paris: OECD.

Carlsson, F., \& Lundström, S. (2002). Economic freedom and growth: Decomposing the effects. Public Choice, 112(3-4), 335-344.

Cebula, R. J. (2011). The impact of property rights freedom on economic growth: Evidence from the OECD nations. Retrieved from http://www.ijeronline.com

Clark, J. R., \& Lawson, R. A. (2008). The impact of economic growth, tax policy and economic freedom on income inequality. The Journal of Private Enterprise, 24(1), 23-31.

Devereux, M. (2011). Transparency in reporting financial data by multinational corporations. Oxford: Oxford University Centre for Business Studies.

Egger, P., \& Winner, H. (2004). Economic freedom and taxation: Is there a trade-off in the locational competition between countries?. Public Choice, 118(3/4), 271-788.

Fraser Institute \& Cato Institute. (2009). Economic freedom of the world. Annual Report, Fraser Institute.

Gwartney, J., \& Lawson, R. (2001). The concept and measurement of economic freedom. Proceedings from the Meeting of Analysis and Measurement of Freedom: Theoretical, Empirical, and Institutional Perspectives Conference. Palermo, Italy.

Gwartney, J., \& Lawson, R. (2003). The concept and measurement of economic freedom. European Journal of Political Economy, 19, 405-430.

Gwartney, J., Lawson, R., \& Easterly, W. (2006). Economic freedom of the world: 2006 annual report. Retrieved from http://www.freetheworld.com

Gwartney, J., Lawson, R., \& Hall, J. (2012). Economic freedom of the world: 2012. Annual Report, Fraser Institute.

Hasegawa, M., Hoopes, J. L., Ishida, R., \& Slemrod, J. (2012). The effect of public disclosure on reported taxable income: Evidence from individuals and corporations in Japan. Retrieved from http://www-personal.umich.edu/ makotoh/research_files/Japan_disclosure.pdf

Jahnson, S. (1998). Regulatory discretion and the unofficial economy. American Economic Review, 88(2), $387-392$.

Jong-Wha, L. (1993). International comparisons of educational attainment. Journal of Monetary Economics, 32(3), $363-394$.

Koo, R. C. (2011). How to avoid a Eurozone breakup: Solve two key problems. The International Economy, 25(1), 46-48.

KPMG. (2013). The Polish tax system in the evaluation of the III Congress of KPMG tax and accounting (Polski system podatkowy w ocenie uczestników III Kongresu Podatków i Rachunkowości). Polska: KPMG.

Kwaśnicki, W. (2005). Economic liberties—How far is Poland behind the "New Europe”? (Wolności gospodarcze-jak 
pozostaliśmy w tyle za większościq “Nowej Europy”). Warszawa: Wolter Kluwer Polska.

Lucas, R. E. (1988). On the mechanics of economic development. Journal of Monetary Economics, 22(1), 3-42.

Mayer, T. (1982). The influence of the modern monetary theory on the U.S. monetary policy (Der Einfluss der moderne Geldtheorie auf die amerikanische Geldpolitik). In P. Szpunar (Ed.), Monetary policy (Polityka pieniężna). PWE, Warszawa.

Mitchell, D. (2007). The tax gap mirage. Retrieved from http://www.cato.org/publications/tax-budget-bulletin/tax-gap-mirage

Mitchell, D. (2013). OECD launches new effort to undermine tax competition. Retrieved from http://www.cato.org/sites/cato.org/files/pubs/pdf/tbb_68.pdf

North, D. C. (1990). Institutions, institutional change, and economic performance. Cambridge: Cambridge University Press.

Nyström, K. (2008). The institutions of economic freedom and entrepreneurship: Evidence from panel data. Public Choice, 136(403), 269-282.

OECD. (1998). Forces sharping tax policy. Economic Outlook, 63(1), 258-269.

OECD. (2009a). The crisis beyond. Retrieved from http://www.oecd.org/document/57/0,3443,en_21571361_41723666_42942201_1_11_1,00.htm

OECD. (2009b). For a better world economy. Retrieved from http://www.oecd.org/document/24/0,3343,en_2649_34487_41707672_11_1_1,00.html

OECD. (2010a). Making reform happen: Lessons from OECD countries. Paris: OECD Publishing.

OECD. (2010b). Offshore voluntary disclosure: Comparative analysis, guidance and policy advice. Retrieved from http://www.oecd.org/tax/exchange-of-tax-information/46244704.pdf

OECD. (2011). Fiscal consolidation: The need for evidence based decision making. Retrieved from http://dx.doi.org/10.1787/gov_glance-2011-6-en

OECD. (2013). Addressing base erosion and profit shifting. Retrieved from http://www.oecd.org/ctp/BEPSENG.pdf

Ricardo, D. (1912). The principles of political economy. London: J.M. Dent.

Romer, P. M. (1990). Endogenous technological changes. Journal of Political Economy, 98(5), S71-S102.

Schneider, F. (2006). Shadow economies of 145 countries all over the world. In D. Mitchell (Ed.), The tax gap mirage. Tax\&Budget Bulletin No. 44.

Schneider, F., \& Enste, D. (2002). Hiding in the shadows: The growth of the underground economy. Retrieved from http://www.imf.org/external/pubs/ft/issues/issues30/

Shleifer, A. (2009). The age of Milton Friedman. Journal of Economic Literature, 47(1), 123-135.

Slemrod, J., Hasegawa, M., Hoopes, J., \& Ishida, R. (2012). The effect of public disclosure on reported taxable income: Evidence from individuals and corporations in Japan. Retrieved http://www-personal.umich.edu/ makotoh/research_files/Japan_disclosure.pdf

Smith, A. (1776). An inquiry into the nature and causes of the wealth of nations. Chicago: University of Chicago Press.

Smith, A. (1954). An inquiry into the nature and causes of the wealth of nations (Badania nad natura i przyczynami bogactwa narodów). Warszawa: PWN.

Solow, R. M. (1956). Contribution to the theory of economic growth. Quarterly Journal of Economics, 70(1), 65-94.

World Bank. (2010). Asset disclosure and conflicts of interest. Retrieved from http://www.worldbank.org/en/news/press-release/2012/11/08 